\title{
PARAGANGLIOMA OF THE NASAL CAVITY. CASE REPORT
}

\author{
Popov M. M., Ognivenko O. V., Lisovets O. V., Sorokina O. G., Olenych V. B.
}

Paraganglioma is one of the tumors that is rarely found in the practice of an otorhinolaryngologist. Approximately $90 \%$ of tumors from nonchromaffin paraganglia occur in the adrenal glands. Nevertheless, $5-$ $10 \%$ of paragangliomas have different localization: $85 \%$ - in the abdominal cavity, $12 \%$ - in the chest, $3 \%$ on the head and neck. Paraganglioma grows slowly, but there is a risk of its degeneration into a malignant neoplasm. Diagnosis of paraganglioma includes CT, MRI; Ultrasound scintigraphy, arteriography, biopsy, histological examination. The main treatment for this education is surgical. As this tumor occurs rather rarely, we present a clinical observation of a paraganglioma of the nasal cavity.

Purposes. The purpose of this article is to describe a rare clinical case of paraganglioma of the nasal cavity to determine diagnostic measures and treatment tactics to help a practical doctor.

Materials and methods. On 01/18/2019 patient M., 52 years old, with complaints of recurrent nosebleeds, difficulty breathing in the right half of the nose was received at the ENT Center «V. T. Lisovets Dynasty». Bleeding from the nasal cavity has been disturbing the patient twice a week for 6 months, for no apparent reason. An increase in the frequency of bleeding up to 4-5 times a week has been noticed for the last month. On a series of MRI tomograms dated 12.24.2019, in the front sections of the nasal concha, on the right, a volumetric pathological formation with dimensions of about $10 \times 12 \mathrm{~mm}$, with tuberous contours, an inhomogeneous MR structure was determined. Bone structures were not affected. The neoplasm narrowed the lumen of the nasal cavity on the right. Conclusion: MR-picture of the pathological volumetric formation (of blastomatous nature) of the nasal cavity on the right.

Results. On 01/21/2019 the patient underwent surgical removal of the neoplasm within healthy tissues using a radioknife. An anterior nasal tamponade with a hemostatic preparation was performed. The postoperative period was without complications. A morphological examination of surgical material $\mathrm{N}$ 330/2019 yielded the following results: a microscopic examination determined a tumor with the same histological picture in the form of alveolar and solid areas, a branched network of blood vessels of capillary type, fibrous tissue of various thicknesses. Tumor parenchyma was represented by epithelioid morphology cells with pronounced eosinophilic cytoplasm, a large nucleus with granular chromatin. Cells with a weakly expressed eosinophilic cytoplasm, with small monomorphic nuclei were also found.

Conclusions. The patient was diagnosed with a rare tumor of neuroectodermal nature, which in most cases has a benign nature, slow growth and develops from nonchromaffin ganglia, which are scattered throughout the body. As the formation grows, the arterial and venous network of vessels develops. The clinical picture of a neoplasm of the nasal cavity is often masked by the symptoms of chronic polypousrhinosinusitis, vasomotor and chronic hypertrophic rhinitis.

Based on the foregoing, this clinical cases valuable for the practitioner in terms of the features of localization, diagnosis and these lection of the correct therapy for this category of patients.

KEY WORDS: paraganglioma, nasal cavity, diagnosis, treatment

\section{INFORMATION ABOUT AUTHORS}

Popov Mykola, Full Professor, Department of General and Clinical Immunology and Allergology, School of Medicine, V. N. Karazin Kharkiv National University, 6, Svobody sq., Kharkiv, Ukraine, 06122, e-mail: mykola.m.popov@karazin.ua, ORCID ID: https://orcid.org/0000-0002-5759-9654

Ognivenko Olena, Candidate of Medicine, Associate Professor, Department of General and Clinical Immunology and Allergology, School of Medicine, V. N. Karazin Kharkiv National University, 6, Svobody sq., Kharkiv, Ukraine, 61022, e-mail: ognivo38@gmail.com, ORCID ID: https://orcid.org/0000-0003-3936-0305

Lisovets Olena, doctor - ENT specialist, Director of the ENT Center «V. T. Lisovets Dynasty», 19-a, Mironositskaya str., Kharkov, Ukraine, 61022, e-mail: lisovets.lor@gmail.com

Sorokina Olga, Candidate of Medicine, Associate Professor, Department of General and Clinical Immunology and Allergology, School of Medicine, V. N. Karazin Kharkiv National University, 6, Svobody sq., Kharkov, Ukraine, 61022, e-mail: olga-sorokina@ukr.net, ORCID ID: https://orcid.org/0000-0001-6646-544X

Olenych Vera, Candidate of Medicine, Associate Professor, Department of General and Clinical Immunology and Allergology, School of Medicine, V. N. Karazin Kharkiv National University, 6, Svobody sq., Kharkov, Ukraine, 61022, e-mail: olenichvera@gmail.com, ORCID ID: https://orcid.org/0000-0002-4776-1486 


\section{INTRODUCTION}

Paraganglioma is one of the tumors that is rarely found in the practice of an otorhinolaryngologist. In the literature, this pathology is also found under the name glomus tumor, or chemodectoma. Paraganglioma develops from nonchromaffin paraganglia, consists of cellular elements that make up the chemoreceptor system. Approximately $90 \%$ of tumors from nonchromaffin paraganglia occur in the adrenal glands. Nevertheless, $5-10 \%$ of paragangliomas have different localization: $85 \%$ - in the abdominal cavity, $12 \%$ - in the chest, $3 \%-$ on the head and neck. Paraganglioma is a disease that accounts for about $0.6 \%$ of all neoplasms of the head and neck $[1,2]$. The first chemododectom was described by Marschand F. in 1891 [3].

In the neck, glomus tumors are most often found in the carotid gland, the region of the jugular glomus and ganglia of the vagus nerve [4].

Paraganglioma grows slowly, but there is a risk of its degeneration into a malignant neoplasm [5].

Diagnosis of paraganglioma includes CT, MRI; Ultrasound scintigraphy, arteriography, biopsy, histological examination.

The method of choice for establishing a diagnosis is magnetic resonance imaging $[4,6]$. Detection of a characteristic «salt-pepper» granularity on a T1-weighted image is a reliable and specific criterion for hemodectomy.

Currently, a puncture biopsy of a hemodectoma is rarely used. The reason is the improvement of tumor imaging methods, low information content of the study itself due to the histological features of the tumor, as well as a high risk of bleeding [7].

As a rule, the treatment of paraganglioma involves the use of the following methods:

- minimally invasive endoscopic intervention;

- stereotactic radiosurgery (using Novalis, Cyber-knife, Gamma-knife);

- radiation therapy;

- embolization;

- surgery;

- a combination of several techniques.

The use of radiation therapy in the case of chemodectomy treatment is minimized due to the possibility of recurrence under the influence of small doses of radiation. Intensive irradiation of the paraganglioma can lead to radiation complications. Some authors argue that radiation therapy is an alternative treatment only for patients who have a high operational risk, multiple relapses, malignant, massive tumor, metastases [8]. In view of the foregoing, most surgeons prefer to use surgical methods of treatment.

Due to the rarity of the occurrence of this tumor, we present a clinical observation of a paraganglioma of the nasal cavity.

\section{CLINICAL CASE}

On January 18, 2019 patient M., 52 years old, was admitted at the ENT center «V. T. Lisovets Dynasty» with complaints of periodic nosebleeds, shortness of breath in the right half of the nose.

Medical history. Bleeding from the nasal cavity has been disturbing the patient 2 times a week for 6 months, for no apparent reason. An increase in bleeding rate up to $4-5$ times a week has been noted for the last month. The patient was examined at the place of residence. With a diagnosis of Hemangioma of the nasal cavity she was admitted for examination and removal of the growth at the ENT Center «V. T. Lisovets Dynasty».

Anamnesis of life. The patient denied infectious and chronic diseases, as well as bad habits. Hereditary diseases were not established. Gynecological history: 1 birth in a natural way, without complications. Menopause from 52 years old, menopause was uneventful. An allergic history is not burdened.

Objective and instrumental examination. Upon admission to the ENT center, an objective and endoscopic examination was performed. Rhinoscopically, the nasal cavity was deformed, narrowed, a tuberous formation with uneven cyanotic contours in the front sections of the left lower nasal conch was determined. In some places the mucous membrane of the formation was ulcerated, areas of hemorrhages were noted. The surface of the formation was uneven, dilated, convoluted submucosal vessels were contouredon the surface. Mucosal infiltration was not determined.

On a series of MRI tomograms dated 12.24.2019, in the front sections of the nasal concha, on the right, a volumetric pathological formation with dimensions of about $10 \times 12$ $\mathrm{mm}$, with tuberous contours, an inhomogeneous MR structure was determined. Bone structures were not affected. The neoplasm narrowed the lumen of the nasal cavity on the right. In the 
parotid and submandibular salivary glands, pathological changes were not detected. Enlarged lymph nodes of the parotid and submandibular region were not determined. Conclusion: MR-picture of the pathological volumetric formation (blastomatous nature) of the nasal cavity on the right.

Treatment. On 01/21/2019 the patient underwent surgical removal of neoplasm within healthy tissues using a radioknife. An anterior nasal tamponade with a hemostatic preparation was performed. The postoperative period was uneventful.

A morphological study of surgical material No. 330/2019 yielded the following results: 1 . A layer of mucous and submucosal tissue without signs of tumor growth. Microscopic examination determined a tumor with the same histological picture in the form of alveolar and solid areas, a branched network of blood vessels of the capillary type, fibrous tissue of various thicknesses. Tumor parenchyma was represented by epithelioid morphology cells with pronounced eosinophilic cytoplasm, a large nucleus with granular chromatin. Cells with a weakly expressed eosinophilic cytoplasm, with small monomorphic nuclei were also present.

Patient M. was discharged with a diagnosis of Paraganglioma of the nasal cavity. Condition after surgical treatment.

Further dynamic follow-up for 1, 3, and 6 months of tumor recurrence (growth of formation, bleeding, metastases) was not found.

\section{CONCLUSIONS}

The clinical picture of a neoplasm of the nasal cavity is often masked by the symptoms of chronic polypous rhinosinusitis, vasomotor and chronic hypertrophic rhinitis.

The doctor's knowledge and the use of noninvasive diagnostic methods (MRI of the paranasal sinuses, endoscopy) allows you to timely diagnose paraganglioma of the nasal cavity with the subsequent selection of the right treatment tactics for this extremely rare pathology in otorhinolaryngology. This will prevent the development of complications, accelerate recovery and, as a result, improve the patient's quality of life.

\section{СПИСОК ЛІТЕРАТУРИ}

1. Хасанов Р. А. Параганглиома гортани. Описание клинического наблюдения / Р. А. Хасанов, Р. А. Азизян, Г.В. Унгиадзе и др. // Опухоли головы и шеи. - 2016. - № 6. - С. 67-70. doi: 10/17650/22221468-2016-6-6-67-70.

2. Кушнир Г. М. Каротидная хемодектома: клинический случай с благоприятным исходом после резекции общей сонной артерии / Г. А. Кушнир, М. М. Иошина, Е. А. Савчук, А. А. Микляев // Международный неврологический журнал. - 2012. - № 5 (51). - С. 72-75.

3. Алферова Ю. С. Современное представление о каротидной хемодектоме и эффективность методов ее лечения / Ю. С. Алферова, В. Д. Сурина, Н. В. Карпов // Казанский медицинский журнал. - 2017. - T. 98, № 5. - C. 792-796. doi: 10/17750/KMJ2017-792/

4. Carroll W. Malignant carotid body tumor / W. Carroll, K. Stenson, S. Stringer // Head Neck. - 2004. - № 26(3). - P. 301-306. doi: 10.1002/hed.20017.

5. Zabel A. Fractionated stereotactic conformal radiotherapy in the management of large chemodectomas of the skull base /A. Zabel, S. Milker-Zabel, P. Huber, D. Schulz-Ertner, W. Schlegel, M. Wannenmacher, J. Debus // Int. J. Radiat. Oncol. Biol. Phys. - 2004. - № 58. - P.1445-1450. doi:10.1016/j.ijrobp.2003.09.070.

6. Митин Ю.В. Первичное излучение тимпаноюгулярной парагангиломы. Вестн. оторинолар. - 1968. - № 2. - C.109-110.

7. Ketabchi S. Paraganglioma of the nasal cavity: a case report. /S. Ketabchi, D. Massi, R. Santoro, A. Franchi // Eur Arch Otorhinolaryngol. - 2003. - № 260. - P. 336-340. doi:10.1007/s00405-002-0569-4.

8. Granato L. Nasal paraganglioma: A case report and literature review / Lídio Granato, José Donato Próspero, Dino Martini Filho // Int Arch Otorinolaryngol. - 2013. - № 17 (1). - P. 92-95. doi: 10.7162/S1809-97772013000100016.

9. Nguyen Q.A. Malignant nasal paraganglioma: a case report and review of the literature. /Q. A. Nguyen, P. M. Gibbs, D. H. Rice// Otolaryngol Head Neck Surg. - 1995. - № 113. - P. 157-61.

10. Бежанова С. Д. Параганглиома гортани / С. Д. Бежанова, Р. А. Хасанов, А. И. Павловская, Е. А. Смирнова // Архив патологии. - 2017. - № 79 (5) - С. 34 - 37. doi: 10.17116/patol201779534-37. 


\section{REFERENCES}

1. Khasanov, R. A., Azizyan, R. A., Ungiadzeetal, G. V. (2016). Paraganglioma of the larynx. Description of clinical observation. Tumors of the head and neck, 6, 67-70. doi:10/17650/2222-1468-2016-6-6-67-70.

2. Kushnir, G. M., Ioshina, M. M., Savchuk, E. A., Miklyaev A. A. (2012). Carotid chemodectoma: a clinical case with a favorable outcome after resection of the common carotid artery. International Neurological Journal, 5 (51), 72-75.

3. Alferova, Yu. S., Surin, V. D., Karpov, N. V. (2017). Current concept of a carotid chemodectome and the effectiveness of methods of its treatment. Kazan Medical Journal, 98(5), 792-796. doi: 10/17750/KMJ2017-792/.

4. Carroll, W., Stenson, K., Stringer, S. (2004). Malignant carotid body tumor. Head Neck, 26(3), 301-306. doi:10.1002/hed.20017.

5. Zabel, A., Milker-Zabel, S., Huber, P., Schulz-Ertner, D., Schlegel, W., Wannenmacher, M., Debus, J. (2004). Fractionated stereotactic conformal radiotherapy in the management of large chemodectomas of the skull base. Int. J. Radiat. Oncol. Biol. Phys, 5, 1445-1450. doi:10.1016/j.ijrobp.2003.09.070.

6. Mitin Yu.V. (1968). Primary radiation of tympanoyugularparagangiloma. Bulletin of otorhinolar, 2, 109110.

7. Ketabchi, S., Massi, D., Santoro, R., Franchi, A. (2003). Paraganglioma of the nasal cavity: a case report. Eur Arch Otorhinolaryngol, 260, 336-340. doi: 10.1007/s00405-002-0569-4.

8. Granato, L., Donato Próspero, J., Martini Filho, D. (2013). Nasal paraganglioma: A case report and literature review. Int Arch Otorinolaryngol, 17(1), 92-95. doi:10.7162/S1809-97772013000100016.

9. Nguyen, Q. A., Gibbs, P. M., Rice, D. H. (1995). Malignant nasal paraganglioma: a case report and review of the literature. Otolaryngol Head Neck Surg, 113, 157-61.

10. Bezhanova, S. D., Khasanov, R. A., Pavlovskaya, A. I., Smirnova, E. A. (2017). Paraganglioma of the larynx. Archive of Pathology, 79(5), 34-37. doi: 10.17116/patol201779534-37.

\section{ПАРАГАНГЛІОМА ПОРОЖНИНИ НОСА. КЛІНІЧНИЙ ВИПАДОК}

\section{Попов М. М., Огнівенко О. В., Лісовець О. В., Сорокіна О. Г, Оленич В. Б.}

Парагангліома - це одна $з$ пухлин, яка рідко зустрічається в практиці оториноларинголога. Діагностика парагангліоми включає КТ, МРТ, УЗД сцинтіграфію, артеріографію, біопсію, гістологічні дослідження. Основним методом лікування даного утворення $є$ хірургічний.

Метою було описання рідкісного клінічного випадку парагангліоми порожнини носа для визначення діагностичних заходів і тактики лікування в допомогу практичному лікарю.

Матеріали та методи. У Лор-центр «Династія імені В.Т. Лісовця» надійшла пацієнтка М., 52 роки, зі скаргами на періодичні кровотечі з носа, утруднене дихання правої половини носа. Проведено об'єктивне і ендоскопічне дослідження. На серії МР-томограм картина патологічного об'ємного утворення (бластоматозного характеру) порожнини носа справа.

Результати. Пацієнтці було виконано оперативне видалення утворення в межах здорових тканин із застосуванням радіоножа. Проведена передня тампонада носа тампоном Merocel з гемостатиком. Післяопераційний період протікав без ускладнень. При мікроскопічному дослідженні визначалася пухлина з однотипною гістологічної картиною у вигляді альвеолярних і солідних ділянок, гіллястої мережею кровоносних судин капілярного типу, фіброзної тканиною різної товщини. Паренхіма пухлини представлена клітинами епітеліоїдної морфології з вираженою еозинофільною цитоплазмою, великим ядром з зернистим хроматином. Також були присутні клітини зі слабко вираженою еозинофільної цитоплазмою, з дрібними мономорфними ядрами.

Висновки. У пацієнтки була діагностована рідкісна пухлина нейроектодермальної природи. Клінічна картина новоутворення порожнини носа часто маскується за симптомами хронічного поліпозного риносинуситу, вазомоторного і хронічного гіпертрофічного риніту. Даний клінічний випадок є цінним для практикуючого лікаря в плані особливості локалізації, діагностики та виборі коректної терапії для цієї категорії пацієнтів.

КЛЮЧОВІ СЛОВА: парагангліома, порожнина носа, діагностика, лікування

\section{ИНФОРМАЩЯ ПРО АВТОРІВ}

Попов Микола Миколайович, д.мед.н., професор кафедри загальної та клінічної імунології та алергології медичного факультету Харківського національного університету імені В. Н. Каразіна, пл. Свободи, 6, Харків, Україна, 61022, e-mail: mykola.m.popov@karazin.ua, ORCID ID: https://orcid.org/0000-0002-5759-9654 
Огнівенко Олена Володимирівна, к.мед.н., доцент кафедри загальної та клінічної імунології та алергології медичного факультету Харківського національного університету імені В. Н. Каразіна, пл. Свободи, 6, Харків, Україна, 61022, e-mail: ognivo38@gmail.com, ORCID ID: https://orcid.org/0000-0003-3936-0305

Лісовець Олена Володимирівна, лікар-оториноларинголог, директор Лор-центра «Династія імені В. Т. Лісовця», вул. Мироносицька, 19-а, Харків, Україна, 61022, e-mail: lisovets.lor@gmail.com

Сорокіна Ольга Георгіївна, к.мед.н., доцент кафедри загальної та клінічної імунології та алергології медичного факультету Харківського національного університету імені В. Н. Каразіна, пл. Свободи, 6, Харків, Україна, 61022, e-mail: olga-sorokina@ukr.net, ORCID ID: https://orcid.org/0000-0001-6646-544X

Оленич Віра Бейбалаївна, к.мед.н., доцент кафедри загальної та клінічної імунології та алергології медичного факультету Харківського національного університету імені В. Н.Каразіна, пл. Свободи, 6, Харків, Україна, 61022, e-mail: olenichvera@gmail.com, ORCID ID: https://orcid.org/0000-0002-4776-1486

\section{ПАРАГАНГЛИОМА ПОЛОСТИ НОСА. КЛИНИЧЕСКИЙ СЛУЧАЙ}

\section{Попов Н. Н., Огнивенко Е. В., Лисовец Е. В., Сорокина О. Г, Оленич В. Б.}

Параганглиома - это одна из опухолей, которая редко встречается в практике оториноларинголога. Диагностика параганглиомы включает КТ, МРТ, УЗИ сцинтиграфию, артериографию, биопсию, гистологические исследования. Основным методом лечения данного образования является хирургический.

Целью было описание редкого клинического случая параганглиомы полости носа для определения диагностических мероприятий и тактики лечения в помощь практическому врачу.

Материалы и методы. В Лор-центр «Династия имени В. Т. Лисовца» поступила пациентка М., 52 года, с жалобами на периодические кровотечения из носа, затрудненное дыхание правой половины носа. Проведено объективное и эндоскопическое исследование. На серии МР-томограмм картина патологического обьемного образования (бластоматозного характера) полости носа справа.

Результаты. Пациентке было выполнено оперативное удаление образования в пределах здоровых тканей с применением радионожа. Произведена передняя тампонада носа тампоном Merocel c гемостатиком. Послеоперационный период протекал без осложнений. При микроскопическом исследовании определялась опухоль с однотипной гистологической картиной в виде альвеолярных и солидных участков, ветвистой сетью кровеносных сосудов капиллярного типа, фиброзной тканью различной толщины. Паренхима опухоли представлена клетками эпителиоидной морфологии с выраженной эозинофильной цитоплазмой, крупным ядром с зернистым хроматином. Также присутствовали клетки со слабо выраженной эозинофильной цитоплазмой, с мелкими мономорфными ядрами.

Выводы. У пациентки была диагностирована редкая опухоль нейроэктодермальной природы. Клиническая картина новообразования полости носа зачастую маскируется за симптомами хронического полипозного риносинусита, вазомоторного и хронического гипертрофического ринита. Данный клинический случай является ценным для практикующего врача в плане особенности локализации, диагностики и выборе корректной терапии для этой категории пациентов.

КЛЮЧЕВЫЕ СЛОВА: параганглиома, полость носа, диагностика, лечение

\section{ИНФОРМАЦИЯ ОБ АВТОРАХ}

Попов Николай Николаевич, д.мед.н., профессор кафедры общей и клинической иммунологии и аллергологии медицинского факультета Харьковского национального университета имени В. Н. Каразина, пл. Свободы, 6, Харьков, Украина, 61022, e-mail: mykola.m.popov@karazin.ua, ORCID ID: https://orcid.org/0000-0002-5759-9654

Огнивенко Елена Владимировна, к.мед.н., доцент кафедры общей и клинической иммунологии и аллергологии медицинского факультета Харьковского национального университета имени В. Н. Каразина, пл. Свободы, 6, Харьков, Украина, 61022, e-mail: ognivo38@ gmail.com, ORCID ID: https://orcid.org/0000-0003-3936-0305

Лисовец Елена Владимировна, врач-оториноларинголог, директор Лор-центра «Династия имени В. Т. Лисовца», ул. Мироносицкая, 19-а, Харьков, Украина, 61022, e-mail: lisovets.lor@gmail.com

Сорокина Ольга Георгиевна, к.мед.н., доцент кафедры общей и клинической иммунологии и аллергологии медицинского факультета Харьковского национального университета имени В. Н. Каразина, пл. Свободы, 6, Харьков, Украина, 61022, e-mail: olga-sorokina@ukr.net, ORCID ID: https://orcid.org/0000-0001-6646-544X

Оленич Вера Бейбалаевна, к.мед.н., доцент кафедры общей и клинической иммунологии и аллергологии медицинского факультета Харьковского национального университета имени В. Н. Каразина, пл. Свободы, 6, Харьков, Украина, 61022, e-mail : olenichvera@gmail.com, ORCID ID: https://orcid.org/0000-0002-4776-1486 